\title{
Exploring alkaline pre-treatment of microalgal biomass for bioethanol production
}

\begin{abstract}
We have investigated, for the first time, the alkaline pre-treatment of microalgal biomass, from the species Chlorococcum infusionum, using $\mathrm{NaOH}$ for bioethanol production. This pre-treatment step aims to release and breakdown entrapped polysaccharides in the microalgae cell walls into fermentable subunits. Three parameters were examined here; the concentration of $\mathrm{NaOH}$, temperature and the pre-treatment time. The bioethanol concentration, glucose concentration and the cell size were studied in order to determine the effectiveness of the pre-treatment process. Microscopic analysis was performed to confirm cell rupturing, the highest glucose yield was determined to be $350 \mathrm{mg} / \mathrm{g}$, and the maximum bioethanol yield obtained was $0.26 \mathrm{~g}$ ethanol/g algae using $0.75 \%(\mathrm{w} / \mathrm{v})$ of $\mathrm{NaOH}$ and $120{ }^{\circ} \mathrm{C}$ for $30 \mathrm{~min}$. Overall, the alkaline pre-treatment method proved to be promising option to pretreat microalgal biomass for bioethanol production.
\end{abstract}

Keyword: Alkaline pre-treatment; Microalgae; Biomass; Fermentation; Bioethanol 